\title{
СВРОПЕЙСЬКИЙ ТА ПІВНІЧНОАМЕРИКАНСЬКИЙ ДОСВІД ЗАПОБІГАННЯ ВУЛИЧНОї ЗЛОЧИННОСТІ
}

\author{
НАЗИМКО Сгор Сергійович - доктор юридичних наук, старший науковий \\ співробітник, перший проректор Донецького юридичного інституту МВС України \\ БЕЛІКОВ Костянтин Аркадійович - заступник Криворізького міського \\ голови
}

DOI:10.32782/NP.2020.1.14

В рамках даної науково-правничої статті автор розглянув усі необхідні складові наиіонального кримінологічного та правоохоронного досвіду окремих держав Европи та Північної Америки із попередження проявів вуличної злочинності. Розглядаючи вказане, автори звертаються до наукових праць окремих вітчизняних та зарубіжних бахівиів із даної кримінологічної проблематики.

Констатовано, що бормулювання та реалізачія заходів $i_{3}$ завчасного попередження всіх відомих проявів вуличної злочинності $\epsilon$ актуальним, нагальним завданням для всіх держав Свропи та Північної Америки.

Акиентовано увагу на тому, шо кримінологічна проблема відтворюється як проблема дитячої, підліткової, а також «бідноӥ», «неблагополучної» злочинності. Причому вона є надзвичайно притаманною державам/суспільствам, які відносяться до розвинутих у сочіально-економічному плані та іншому.

Заходи, які вживаються в розвинутих крайнах для попередження такої злочинносmi, зводяться, по-перше, до якомога раннъого усунення шкідливих соціально-економічних, культурних, політичних та інших бакторів, які сприяють системно-перманентному відтворенню вуличної злочинності. По-друге, такі заходи носять пробілактично-виховний та роз'яснювально-освітній характер. Потрете, вживаються класичні правоохоронні практики. По-четверте, великого значення має еџективна співпраия правоохоронних органів із представниками громадсъкості (громадсъкими, релігійними організачіями), працівниками системи сочіального забезпечення.

У рамках тих чи інших заходів із попередження вуличної злочинності, попередження віктимізаиій суспільства від дій ї̈ представників особливого значення надається проблематиці застосування засобів особистої самооборони, зокрема ліберальної чи, навпаки, заборонної політики у сфері реалізацій права громадян на володіння вогнепальною та іншою зброєю. Моделі такої політики надають вищенаведені як позитивні, так $i$ «зеркальні» негативні результати. Однак подолання проблеми вуличної злочинності залежить від злагоджених зусиль всъого суспільства.

Ключові слова: вулична злочинність, види вуличних злочинів, начіональний досвід попередження вуличноӥ злочинності, окремі держави Европи та Північної Америки.

Усі без виключення кримінальні злочини, незалежно від видів та масштабів цих протиправних діянь, а також конкретних обставин та способів їх вчинення, відображають природні цілі злочинних посягань як таких. Ними є оволодіння чужою рухомою та нерухомою власністю, замах на позитивний психоемоційний стан (політичні злочини, тероризм), фізичну недоторканність, здоров'я та життя людей.

Отже, мова йде про те, що офіційні правоохоронні органи, громадські інституції та науковці-правники мають докласти всіх необхідних та можливих сукупних зусиль заради якомога широкого викорінення на- 
віть і тієї злочинності, яку умовно можна віднести до «злочинності низького побутового рівня».

На нашу думку, саме вулична злочинність і $е$ яскравим прикладом щойно наведеної нами авторської, безумовно, дещо штучної кримінологічної дефініції [1].

Сучасна вулична злочинність є гострою, невирішеною соціальною проблемою переважної більшості держав, незалежно від їхньої етнічної, конфесійної та географічної належності, досягнутого рівня соціальноекономічного розвитку, виду політичної системи тощо.

Основними категоріями, які визначають і схожість, i, навпаки, унікальність національного досвіду окремих держав Західної Европи та Північної Америки у боротьбі із вуличною злочинністю, є: 1) загальне поняття про вулицю - місце вчинення кримінальних злочинів, яке безпосередньо обумовлює власне обставини їхнього вчинення; 2) найрізноманітніші заходи, дії iз попередження тих чи інших вуличних злочинів, реагування на їхній тій чи іншій стадії.

Усі інші важливі предметні категорії, наприклад, конкретні види вуличних злочинів, матеріальні, соціальні та психологічні наслідки їхнього вчинення, моральнопсихологічний настрій вуличних злочинців та їхніх жертв тощо, - обумовлюються саме цими двома показниками. В українському законодавстві не існуе нормативізованого визначення вулиці, зокрема у їі суто кримінологічному вимірі.

Таким чином, саме структурно-функціональний підхід відтворює необхідний нам предметно-кримінологічний вимір поняття «вулиця». Факт або ж стан того, що «вулиця є сферою з невизначеним набором потенційних учасників» говорить про те, що «учасниками» такої сфери потенційно можуть бути і люди із злочинними намірами, які вони («публічно», «на вулиці») втілюють у конкретні злочинні дії. У свою чергу, саме «вуличність», публічність і обумовлюють всі вищевказані другорядні, підпорядковані, суміжні категорії даної кримінологічної проблематики. I, отже, під вуличними злочинами нам слід розуміти, таким чи- ном, кримінальні злочини, які вчиняються, скажімо так, переважно «публічно», «на людях», «серед білого дня», «не приховуючись», «відкрито».

У середньому, по всіх країнах світу, вулична злочинність розподіляється на наступні «галузево-цільові сегменти» (подається в авторському перекладі з мови-оригіналу джерела): «У структурі вуличної злочинності крадіжки складають $12 \%$, а якщо виділити окремо кишенькові крадіжки, то їх виявиться $6 \%$, пограбування - $14 \%$, розбої - $12 \%$, хуліганство та вандалізм - $19 \%$, згвалтування та інші сексуальні дії - $10 \%$, вбивства - 7 \%, завдання шкоди різної тяжкості здоров'ю - 12 \%. Решта 8 \% припадає на викрадення автомобілів, кримінальнокаральні дорожньо-транспортні злочини, побиття, пов'язані із кримінальними бійками» [6, с. 67-68].

Великого значення має і кримінологічний портрет пересічного вуличного злочинця. Так, А.М. Прозументов та Н.М. Рачкова пишуть (подається в авторському перекладі 3 мови-оригіналу джерела): «Вуличні злочинці - це, як правило, молоді люди у віці від 18 до 25 років із антисуспільною установкою, яка сформувалася на фоні вживання алкоголю та наркотиків. При цьому, попре те, що особи, які скоїли злочини на вулицях, є найбільш економічно активною частиною населення, вони у переважній своїй більшості ніде не працюють і не навчаються. Ті, хто мали роботу на момент вчинення злочину, $є$ представниками низькокваліфікованих професій» [7, с. 25].

Засновуючись на тому, що вулична злочинність $\epsilon$ соціальним явищем, яке відтворює свої суто соціальні (соціально-економічні, морально-ціннісні) причини та складові, боротьба із нею постає у вигляді, насамперед, попередження тих негативних соціальних чинників, які іiі породжують. Таким чином, насамперед мова йде про профілактичні антикриміногенні дії, яким у державах Европи та Північної Америки приділяється велике значення у боротьбі із вуличною злочинністю.

Так, В.К. Григорян зазначає (подається в авторському перекладі 3 мови-оригіналу джерела): «Протягом останніх двох 


\section{Кримінальне право, кримінальний процес та криміналістика}

десятиліть у західноєвропейських країнах та США, Канаді і Японії активно розвиваються теорія та практика попередження злочинів. При цьому кримінологи західних країн воліють вести мову не про попередження злочинності як соціального явища, а лише про її обмеження, стримуючий вплив на конкретні криміногенні чинники та обставини. Тим не менше, в практичному аспекті попередження злочинів робиться дуже багато. Передбачається, що попередження не може бути ефективним, якщо воно не організовано на систематичній i скоординованій основі і не включає заходів iз покращення життя населення, удосконалення кримінального правосуддя» $[4, \mathrm{c}$. 272-273].

Сказане в надзвичайно великій мірі стосується проблеми вуличної злочинності, котра, як ми щойно зазначили, є, скажімо так, 3 одного боку, «злочинністю з боку юнацтва та молоді», а з іншого, «злочинністю людей без освіти, людей низької кваліфікації та малого заробітку».

В узагальненому вигляді комплексний національний досвід Федеративної Республіки Німеччина (надалі - ФРН) у боротьбі із вуличною злочинністю можна звести до наступного (подається в авторському перекладі 3 мови-оригіналу джерела): «1) 3бір інформації, планування, виконання та оцінка програм із попередження вуличних злочинів; 2) Координація діяльності поліції та інших органів, які працюють у цій сфері;3) Забезпечення участі населення; 4) Співробітництво із засобами масової інформації; 5) Науково-дослідницька робота; 6) Співробітництво із законодавчими органами, які визначають політику у сфері боротьби із злочинністю; 7) «Навчальна підготовка» [4, с. 273].

Так, перший із вказаних пунктів передбачає оперативну широку роботу, зокрема агентурні дії у колах вуличної злочинності. Змістом другого пункту є взаємодія правоохоронних структур із органами опіки над неповнолітніми особами, із дитячими притулками, батьківськими комітетами, молодіжними радами, центрами психологічної та постнаркотичної реабілітації неповнолітніх осіб тощо. Згідно з третім пунктом залучення населення до активної допомоги силам поліції є надзвичайно важливим елементом протидії вуличній злочинності. Великого профілактичного значення має i відповідний внесок ЗМІ, які сприяють широкій гласності цієї проблеми.

Ефективна боротьба із вуличною злочинністю має будуватися на фундаментальній та прикладній науковій основі. Власне i без зрозумілого та максимально досконалого кримінального та адміністративного законодавства неможливо подолати вуличну злочинність.

Ефективне застосування всіх вказаних інструментів не є можливим без проходження працівниками поліції грунтовної навчально-професійної підготовки та перепідготовки. Власне кримінальне покарання через засудження вуличного злочинця є крайньою мірою. Тому всі вказані попереджувальні дії повинні сприяти якомога меншому застосуванню норм та санкцій КК $\Phi$ РH.

Що стосується такого важливого пункту як участь громадян у підтриманні правопорядку на вулицях, то подібні дії широко та успішно практикуються в Сполучених Штатах Америки (США) та Канаді. Так, В.К. Григорян зазначає з цього приводу наступне (подається в авторському перекладі 3 мови-оригіналу джерела): «У деяких штатах (США. - Прим. aвm.) участь громадян у зміцненні правопорядку дозволило знизити кількість пограбувань на $30 \%$. Тут (у США. - Прим. авт.) використовується винагорода за інформацію, яка має оперативно-профілактичне значення. У Канаді широко практикується участь громадян у патрулюванні. Діючи разом із поліцією, громадські патрулі знижують страх перед злочинцями та підтримують відчуття безпеки. У ряді випадків створюються так звані контрольні пости коло виявлених зон підвищеної злочинної активності, особливо у нічний час» [4, с. 274].

Також заходи із попередження вуличної злочинності, які приймаються та діють у СІІА, засновані, з одного боку, на загальній для всіх держав характеристиці цієї проблеми, а з іншого, на важливій особливості внутрішнього життя цієї країни. Під першою розуміється те, що вулична зло- 
чинність є злочинністю дітей, юнацтва та молоді. Друга ж полягає у тому, що США є багатонаціональним, багаторасовим суспільством. Саме тому сучасна Федеральна програма оздоровлення американського суспільства передбачає: 1) Формування ненасильницьких установок та навичок у підростаючого покоління; 2) Підтримка місцевих общин у справі попередження насильства; 3) Викорінення насадження расової та культурно-національної ворожнечі; обмеження розповсюдження зброї серед громадян; 5) Ідеологічне та матеріальне стимулювання оздоровлення сімейного образу життя; 6) Рекомендації засобам масової інформації щодо скорочення реклами насильства та проведення пропаганди, яка сприяє скороченню насильства; 7) Проведення наукових досліджень, присвячених виявленню умов, у яких попередження злочинів здійснюється найбільш успішно [4, с. 275-276].

Іншими заходами, які вживаються у СІІА для попередження вуличної злочинності та боротьби із нею, є (подається в авторському перекладі 3 мови-оригіналу джерела): «Попередження: відноситься до заходів, які попереджують приєднання людей до вуличних банд. Попередження частіше за все фокусується на молодих людях та приділяє більше уваги ситуаційним причинам злочинності та меншу увагу умовам, які формують криміногенну мотивацію. Втручання: прагнення відволікти членів вуличної банди, які досі не скоїли серйозних кримінальних злочинів, від їхнього образу життя. Численні програми із втручання передбачають координацію правоохоронних органів із громадськими або релігійними організаціями. У рамках цих програм надається можливість освіти, професійної підготовки в якості стимулів для виходу із банди. Придушення: кримінальне переслідування членів банди» [8, с. 282].

Серед численних американських правоохоронних структур слід окремо згадати про стратегію боротьби із вуличною злочинністю, яка реалізовується Федеральним Бюро Розслідувань США (надалі - ФБР).

Так, сучасний американський дослідник Дебора Лем Вайзел зазначає з цього приводу наступне (подається в авторському перекладі 3 мови-оригіналу джерела): «Метою загальнодержавної стратегії ФБР по боротьбі із вуличними бандами, відомої як Розслідування, засноване на «теорії впливу оточення», має на меті ідентифікацію, підрив та остаточну ліквідацію банд, чия діяльність відтворює злочинні складові. Будучи стислою, ця стратегія ФБР реалізується у співробітництві 3 іншими федеральними та місцевими правоохоронними службами. Вона становить боротьбу iз головними в країні вуличними бандами, які розповсюджують наркотики, які становлять суттєву загрозу американському суспільству. Стратегія імплементується через тривалі, багатовекторні, координовані розслідування, що допомагає здійснювати наступне успішне судове переслідування» $[10$, c. 40$]$.

Тактика ФБР із розслідування діяльності вуличних банд, що також є діями попереджувального характеру, передбачає наступне (подається в авторському перекладі 3 мови-оригіналу джерела): «Першим кроком у розслідуванні діяльності будь-якої вуличної банди є ознайомлення із наявними оперативними даними заради оцінки структури групи, характеру членства та протиправної діяльності. Таким чином, здійснюється попереднє розслідування через огляд відомчих матеріалів, доступних та закритих матеріалів, та через призначення інформаторів у такій злочинній групі, що допоможе отримати інформацію про окремих членів та їхні злочинні дії. На цьому етапі слідчий намагається виявити індивідуальні та групові майнові цінності, а також майнові інтереси банди. На наступному етапі слідчі намагаються встановити місця зборів банди, методи спілкування між учасниками банди та матеріальні об'єкти, завдяки яким банда скоює злочинні їхні дії. Це робиться через застосування різноманітних слідчих технік. На цьому етапі слідчий оцінюе та визначає всю кримінальну групу, підприємства, які можуть бути об'єктом розслідування, та потенційно можливі злочинні дії банди» [10, с. 42].

Великого значення має і первинна профілактична робота в рамках американських 


\section{Кримінальне право, кримінальний процес та криміналістика}

освітніх закладів того чи іншого рівня. Так, у США офіцери поліції реалізовують у середніх школах програму «Курс спротиву вуличним бандам». Вона передбачає 13-тижневий курс, який виявляє всі небезпеки приєднання до вуличних банд. Зміст Програми зосереджено на розвитку позитивних пізнавально-поведінкових навичок, соціальних навичок, здатності відмовляти, навичок правильного вирішення конфліктних ситуацій [11].

Іншим прикладом американської подібної програми превентивного характеру є Програма превенції. Вона є спрямованою на попередження антисоціальної поведінки серед хлопчиків віком від 7 до 9 років, належать до груп із низьким соціально економічним статусом та які зіткнулися із протиправною поведінкою у дитячих виховних закладах [11].

Практика союзу між правоохоронними органами та небайдужою, сміливою, фізично та морально підготовленою громадськістю активно застосовується і в Об'єднаному Королівстві Великої Британії та Північної Ірландії (надалі - Великобританія). Так, населення цієї держави активно залучається до співробітництва із поліцією (патрулювання, чергування у найбільш криміногенних районах). Для представників громадськості практикується безплатна видача «поліцейського» обмундирування (без знаків розрізнення та службової атрибутики), засобів радіозв'язку, дубинок, наручників, i навіть зброї для «бойового» патрулювання на поліцейських автомашинах. Уся ця діяльність отримує моральну і матеріальну підтримку суспільства і держави [4, с. 275].

Схожі із американським стратегія і тактика попередження вуличної злочинності діють і в тій чи іншій неєвропейській та неамериканській країні, наприклад, у Японії. Так, Григорян В.К. зазначає (подається в авторському перекладі 3 мови-оригіналу джерела): "Для попередження (в Японії. - Прим. авт.) первинної злочинності (яка частіше за все має форму саме вуличної злочинності. - Прим. авт.), зокрема, виявляються та підлягають індивідуальному виховному впливу складні підлітки у школі; здійснюється широка пропаганда законос- лухняності, яка ведеться силами поліції, школи, громадських організацій; вживаються заходи для усунення умов для здійснення злочинів» [4, с. 277].

Узагальнюючи заходи, спрямовані на ефективне попередження всіх вказаних проявів вуличної злочинності, неможливо оминути і гостру проблематику легалізації володіння вогнепальною зброєю цивільним населенням.

Такий політико-законодавчий крок інституту держави, як вважають прихильники легалізації та права потенційних жертв вуличних злочинів на самооборону, зміг би суттєво скоротити чисельність таких вуличних злочинів як завдання тілесних ушкоджень різного ступеня тяжкості, згвалтування, вбивства, пограбування, хуліганство. Противники ж даного кроку, навпаки, прогнозують широкий неконтрольований сплеск насильства у вигляді вуличної, побутової стрілянини.

Міжнародне ставлення до цього питання слід розглядати під кутом зору наявності різних міждержавних, міжнародно-регіональних моделей. Так, Е.А. Сидоренко стверджує, що на теперішній час виділяються англо-американська, західноєвропейська, східноазійська, соціалістична та інші системи. У рамках типових регіональних систем існують субрегіональні кримінологічні групи. Наприклад, в англо-американському типі виділяються американська та британська кримінологічні моделі $[9$, с. 140$]$.

Так, «цивільний обіг» вогнепальної зброї у СШІА регулюється згідно Поправки № 2 до Конституції США від 1791 року [14] та Федеральним законом США «Про контроль над вогнепальною зброєю» від 1968 року [13]. Зміст вказаної з Поправкою є наступним (подається в авторському перекладі 3 мови-оригіналу джерела): «Оскільки добре організована поліція є необхідною для безпеки вільної держави, право народу на зберігання та носіння зброю не повинно порушуватися» [14].

Вказаний Закон, у свою чергу, встановив суворі обмеження на продаж зброї, передбачив необхідність отримання федеральної ліцензії на їі виробництво, імпорт 
та торгівлю, запровадив заборону на імпорт неспортивної зброї, визначив категорії громадян, яким зброя не може бути продана, обмежив продаж автоматичних та напівавтоматичних зразків тощо [12].

Саме американський досвід обмеженої легалізації вогнепальної зброї свідчить про те, що такий захід має як позитивний, так і негативний підсумок. Наприклад, у період з 1973 по 1990 рр. кількість одиниць приватної вогнепальної зброї збільшилася на $73 \%$, причому кількість вбивств зменшилася на 8,5 \%, згвалтувань - на $5 \%$, нападів - на $7 \%$ [9, с. 140]. Однак, у свою чергу, у 1982 році доля вбивств із використання вогнепальної зброї складала 60 \% [9, с. 140].

Власне легалізація права цивільних осіб на володіння вогнепальною зброєю залежить від політичної ініціативи самих законодавчих зібрань штатів США. Американські дослідники підрахували, що якщо $б$ усі штати, які до 1992 року все ще не мали законів про право громадян на носіння зброї, прийняли б їх в 1992 році, можна б було щороку попереджати 1570 вбивств, 4177 згвалтувань та більш 60000 випадків фізичного насильства [9, с. 141].

Законодавство СШІА у сфері права на володіння цивільними особами вогнепальною зброєю та власне обмеження такого права включає й інші нормативно-правові акти: Федеральний Закон «Про попередження злочинів, пов'язаних із ручною вогнепальною зброєю» від 1993 року (так званий Закон Брейді) [9, с. 141] та Федеральний Закон «Заборона сенатора Лаутенберга» від 1996 року [12].

Дещо інший кримінологічний та нормативно-правовий досвід у контексті вказаного заходу із протидії вуличній злочинності має Великобританія. «Законодавчий акт «Про вогнепальну зброю» від 1997 року заборонив у Великобританії обіг крупнокаліберних мисливських рушниць, пістолетів та револьверів, а на придбання спортивних пістолетів розповсюдив дозвільний (ліцензійний) порядок. Обмеження обігу озброєнь призвело до позитивних кримінологічних результатів. 31997 року у Великобританії відмічається стійка тенденція зниження злочинності. Якщо у 1996 році було зареєстровано 19351 злочин, то в 2009 році - 10 687, тобто на $45 \%$ менше. Порівняно із 1997 роком, рівень злочинності знизився на $36 \%$. Беручи до уваги стабільну та послідовну динаміку спаду злочинності на фоні росту міграції і нелегального експорту зброї, цей показник зниження можна назвати безпрецедентним [9, с. 140-141].

Однак і в рамках вказаної британської моделі, яка є протилежною по відношенню до американської, вжиті законодавчі заходи відтворили зворотний ефект - збільшення кількості насильницьких дій з боку вуличної злочинності по відношенню до законослухняних громадян. Так, попри зафіксоване зниження індексної та насильницької злочинності, в період з 1997 по 2003 рр. рівень вбивств у Великобританії зріс більш ніж на $40 \%$ [9, с. 142].

Таким чином, як ми бачимо, ані американська, ані британська модель державної політики по відношенню до обігу зброї серед цивільного населення не можуть бути соціальною панацеєю у справі повного недопущення кількості вуличних нападів, поранень, вбивств, вуличних озброєних пограбувань. При ширшому дозволі на використання зброї у цілях самозахисту знижується рівень вуличних злочинів, проте зростає чисельність випадків «стрілянини» як такої. Заборона ж володіння вогнепальною зброєю цивільними особами, у свою чергу, через інші причини також призводить до віктимізації суспільства «в умовах вулиці».

Що ж стосується стану справ у ФРН, то там жорсткі заходи органів державної влади із заборони розповсюдження вогнепальної зброї призвели до розвитку нелегального, «чорного ринку» та жодним чином не впливали на динаміку насильницьких 3лочинів у німецькому суспільстві [9, с. 142].

Іншим феноменом, гідним науковокримінологічної уваги, є культура ставлення тих чи інших народів до інституту права, правопорядку. У таких країнах рівень вуличної злочинності $\epsilon$ традиційно дуже низьким. Наприклад, більше чверті громадян Швейцарсъкої Конфедерації (надалі Швейцарія) володіють вогнепальною зброєю. До того ж, у цій державі не прийнято 


\section{Кримінальне право, кримінальний процес та криміналістика}

жодного загальнонаціонального закону про дозвіл чи заборону цивільного володіння зброєю. Проте насильницька, озброєна вулична злочинність характеризується достатньо низькими показниками [9, с. 143].

Достатньо близьким до Швейцарії є досвід попередження вуличної злочинності y країнах Скандинавї, відносне криміногенне благополуччя яких також $є$ результатом соціально-економічної та культурної політики державної влади. Так, північноєвропейська (скандинавська) система кримінологічної профілактики заснована на оптимальному співвідношенні демократії, соціальної політики та громадської довіри. Попередження злочинності (зокрема, безумовно, і вуличної. - Прим. авт.) включає в себе здійснення великомасштабних соціальних заходів із підвищення рівня та якості життя, створенню рівних можливостей для отримання освіти, медичної допомоги та інших послуг, підтримки соціальновразливих категорій населення [9, с. 143].

Зокрема, у Королівстві Швеція політика дозволеної, власне необхідної самооборони зосереджена на застосуванні не справжньої вогнепальної зброї, а пристроїв, конструктивно подібних до зброї, а також холодної, метальної, газової та сигнальної зброї, окремих механізмів (затворів, глушників, барабанів тощо) [9, с. 143]. На сьогодні вогнепальною зброєю у Швеції володіють $15 \%$ населення, при цьому рівень вбивств не перевищує 1,3 на 100000 населення, а озброєних вбивств - 0,18 [9, с. 143].

У свою чергу, всі держави пострадянського простору також дозволили своїм громадянам використання газової зброї самооборони, а в Молдові, Аитві, Аатвї та Ecmoнiі навіть дозволено володіння вогнепальною короткоствольною нарізною зброєю [5, с. 64].

Таким чином, виходячи із всього наведеного та розглянутого, ми доходимо наступних предметних висновків.

Формулювання та реалізація заходів iз завчасного попередження всіх відомих проявів вуличної злочинності $\epsilon$ актуальним, нагальним завданням для всіх держав Европи та Північної Америки.
Ця кримінологічна проблема відтворюється як проблема дитячої, підліткової, а також «бідної», «неблагополучної» злочинності. Причому вона $є$ надзвичайно притаманною державам/суспільствам, які відносяться до розвинутих у соціально-економічному плані та іншому.

Заходи, які вживаються в розвинутих країнах для попередження такої злочинності, зводяться, по-перше, до якомога раннього усунення шкідливих соціальноекономічних, культурних, політичних та інших факторів, які сприяють системноперманентному відтворенню вуличної злочинності. По-друге, такі заходи носять профілактично-виховний та роз'яснювальноосвітній характер. По-третє, вживаються класичні правоохоронні практики. Почетверте, великого значення має ефективна співпраця правоохоронних органів із представниками громадськості (громадськими, релігійними організаціями), працівниками системи соціального забезпечення.

у рамках тих чи інших заходів із попередження вуличної злочинності, попередження віктимізації суспільства від дій їі представників особливого значення надається проблематиці застосування засобів особистої самооборони, зокрема ліберальної чи, навпаки, заборонної політики у сфері реалізації права громадян на володіння вогнепальною та іншою зброєю. Моделі такої політики надають вищенаведені як позитивні, так і «дзеркальні» негативні результати.

Однак подолання проблеми вуличної злочинності залежить від злагоджених зусиль всього суспільства.

\section{Аітература}

1. Беліков К.А. Вулична злочинність в Україні як об'єкт кримінологічного дослідження: поняття та основні прояви. Юридичний науковий електронний журнал. 2019. № 6 .

2. Василевич В.В. Вулична злочинність. Енииклопедія сучасної України. URL: http://esu.com.ua/search_articles. php?id $=301$.

3. Гайдуков Т.В. Понятие уличной насильственной преступности. Вестник Московского университета МВД России. 2017. № 6. 
4. Григорян В.К. Предупреждение преступности в высокоразвитых зарубежных странах. Актуальнъие проблемъ российского права. 2012. № 4 .

5. Зырянов С.М. Административноправовые модели оборота гражданского оружия в российской федерации и в зарубежных странах. Журнал зарубежного законодательства и сравнительного правоведения. 2017. № 1 .

6. Краюшкина М.М. Актуальные вопросы уличной преступности. Вестник Воронежского института МВД России. 2012. № 4.

7. Прозументов А.М., Рачкова Н.M. Уличная преступность: понятие, характеристика и профилактика. Криминологический журнал Байкальского государственного университета экономики и права. 2013. № 2.

8. Селявкин Д.В. Банды как разновидность организованной преступности в Соединенных Штатах Америки. Территория науки. 2013. № 2.

9. Сидоренко Э.А. Зарубежные модели легализации оружия и криминологическая безопасность личности. Общество $u$ право. 2011 . № 1 (33).

10. Deborah Lamm Weisel, Ph.D. The Evolution of Street Gangs: An Examination of Form and Variation. URL: https://pdfs. semanticscholar.org/1726/99e9df55d9f674f1b 21 ea430c2186e3153ce.

11. Jeff Slowikowski. Gang Prevention: An Overview of Research and Programs. Office of Juvenile Justice and Delinquency Prevention. URL: https:/ojjdp.ojp.gov/.

12. Public Law 104-208104th Congress. URL: https:/www.congress.gov/104/plaws/ publ208/PLAW-104publ208.pdf.

13. Public Law 90-618-OCT. 22, 1968. URL: https://www.govinfo.gov/content/pkg/ STATUTE-82/pdf/STATUTE-82-Pg1213.pdf.

14. The Constitution of the United States. URL: https://constitutioncenter.org/media/ files/constitution.pdf.
Within the bounds of the given law study paper the author considered all necessary elements of the national criminological and law enforcing experience of particular European and Northern America states in preventing street crime. Considering the given subject-matter aspects the author was using scientific papers of some national and foreign experts in this criminological field.

It is stated that the formulation and implementation of measures for the early prevention of all known manifestations of street crime is an urgent, urgent task for all states of Europe and North America.

Attention is focused on the fact that the criminological problem is reproduced as the problem of children's, teenagers, as well as «poor», «dysfunctional» crime. Moreover, it is extremely inherent in states / societies that are developed in socio-economic terms and other.

Measures taken in developed countries to prevent such crime are reduced, firstly, to the early elimination of harmful socio-economic, cultural, political and other factors that contribute to the systemic permanent reproduction of street crime. Secondly, such measures are preventive and educational and explanatory and educational in nature. Thirdly, classic law enforcement practices are used. Fourthly, effective cooperation of law enforcement agencies with representatives of the public (public, religious organizations), workers of the social security system is of great importance.

In the framework of various measures to prevent street crime, the prevention of victimization of society from the actions of its representatives, particular importance is attached to the issue of using personal self-defense tools, in particular a liberal or, conversely, forbidden policy in the field of exercising citizens' right to own firearms and other weapons. Models of such a policy have the above positive and «mirror» negative results. However, solving the problem of street crime depends on the coordinated efforts of the whole society.

Key words: street crime, types of street crimes, national experience in preventing street crime, particular European and Northern America states. 